\title{
Mycosis Fungoides and Sezary Syndrome Peripheral Blood Involvement TNM
} Finding v8

National Cancer Institute

\section{Source}

National Cancer Institute. Mycosis Fungoides and Sezary Syndrome Peripheral Blood

Involvement TNM Finding v8. NCI Thesaurus. Code C141322.

A finding about one or more characteristics of mycosis fung oides and Sezary syndrome, following the rules of the TNM AJCC v8 classification system as they pertain to peripheral blood involvement. 